\title{
Parasites, or the Politics of Textual Poetics in Ben Okri's The Famished Road
}

\section{Catherine Lanone}

\section{(2) OpenEdition \\ 1 Journals}

Electronic version

URL: https://journals.openedition.org/ces/5349

DOI: $10.4000 /$ ces.5349

ISSN: 2534-6695

Publisher

SEPC (Société d'études des pays du Commonwealth)

\section{Printed version}

Date of publication: 1 April 2013

Number of pages: $57-66$

ISSN: 2270-0633

\section{Electronic reference}

Catherine Lanone, "Parasites, or the Politics of Textual Poetics in Ben Okri's The Famished Road", Commonwealth Essays and Studies [Online], 35.2 | 2013, Online since 17 April 2021, connection on 23 July 2021. URL: http://journals.openedition.org/ces/5349 ; DOI: https://doi.org/10.4000/ces.5349

\section{(c) $($ †) $\ominus$}

Commonwealth Essays and Studies is licensed under a Licence Creative Commons Attribution - Pas d'Utilisation Commerciale - Pas de Modification 4.0 International. 


\section{Parasites, or the Politics of Textual Poetics in Ben Okri's The Famished Road}

This paper discusses Ben Okri's novel The Famished Road in the light of Michel Serres's analysis of the paradigm of the parasite, both as an animal and/or human predator, and as random noise that disturbs a system through interference. The Famished Road creates textual "noise" through the systematic shift from realism to the supernatural world of spirits, creating textual magic to explore the transition from colonialism to a travesty of democracy. Revisiting the figure of the abiku, transforming motifs like the abiku's buried secret objects, Okri creates a system of encroaching parasites (rats, thugs) which infect the community and transform potentially positive human beings (like the larger-than-life Madame Koto, whose triple pregnancy represents the fate of the fictional equivalent of Nigeria). Thus the novel portrays the precarious lives of a landscape threatened by deforestation and of human beings like the emblematic Mum and Dad, whose resilience equals dispossession.

Like Sterne with Tristram Shandy, Dickens with David Copperfield or Salman Rushdie with Midnight's Children before him, Ben Okri opens The Famished Road with the metatextual birth of his homodiegetic narrator; and like Rushdie, Okri places this birth at a moment of historical significance, the birth of an independent nation, a stylized version of Nigeria in the 1960s. The opening sentence blends oral tradition and biblical overtones to create the hybrid topography of myth, the river of the beginning of time which turns into the eponymous famished road. The image functions as a metaphor for Okri's narrative method, carving the repetitive spiral of endless storytelling within the codified shape of the European teleological Bildungsroman. Critics like Arlene A. Elder find the "narrative shape-shifting" which seeks to graft orature into literature fascinating but problematic, although Okri wants his reader to inhabit a dual world, much in the manner of Azaro himself: "So many things that will seem puzzling in the book are actually in the possibility of a life being lived simultaneously at different levels of consciousness and in different territories" (Okri in Elder 12). The reader must learn to switch from the world of reality to the world of spirits, worlds which constantly interact, as when, in the police officer's house, the spirits of the dead dip their bloody hands into the food. This constant shifting creates "noise," in the sense of interference: "noise, through its presence and absence, the intermittence of the signal, produces the new system" (Serres 52). Indeed, the novel seems to play on what Michel Serres, drawing upon French, defines as the three meanings of the term "parasite," biological parasite, social parasite, and static or interference (xiii). His model may highlight the paradoxical dynamic of the Famished Road, which creates the presence of noise, only to highlight the parasites plaguing the life of the nation, threatening to turn it into a misbegotten welter of festering, hungry wounds.

\section{Animal parasites and rotten milk}

The novel swarms with parasitic presences. When Azaro roams outside and loses his way, he runs the risk of parasitic contamination. For Michel Serres, an animal parasite is "the element of some chain" (189) which cannot be blocked: "it enters the body, and 
infests it" (190). Thus, worms wriggle into Azaro's feet on the road and Mum must carefully extract them with a needle. But there are parasites at home too; the place is infested with rats, which at first seem taken for granted (Azaro's Dad tells his son to listen to what they say), but their apparently inexhaustible supply of corpses becomes disgusting once the photographer poisons them, in a grotesque echo of the Pied Piper story, as Vanessa Guignery points out (170). The rats seem to function both as disgusting parasites and as alter-egos for the poor:

"It's a hard life," he said.

"That's what the rats used to say." (306)

Human beings too run the risk of being poisoned: the beautiful blue dragonfly that materializes out of the white milk powder at night, before Azaro's stunned eyes, is a sign that the milk is rotten; the insect is squashed by Mum into a slimy green blot - one of those green stains, like the drunkard's piss in Madame Koto's bar, that signal a shift from fertility to corruption.

The image is all the more striking as a turquoise dragonfly is unlikely to develop as a milk parasite; but the very word, dragon/fly, corresponds to the metamorphic world of the novel, and the dragon is less the dragonfly than incipient political corruption. The episode of the rotten milk ties in with the main theme of aborted possibility: milk suggests the potentially nurturing function of politics, the rebirth of the mother-land after colonial exploitation and the nation's ability to take care of her own people, to feed them. But the distribution of milk is a travesty of kindness, and a literal symptom of corruption: seeking to buy votes, the canvassers only distribute a powder that is as rotten as their promises; thus we switch from animal parasites to human parasites, like the landlord. The loudspeaker blares its deceptive slogans, an artificial voice which at first seems supernatural to Azaro, but which only offers a mock prophecy heralding some "misbegotten" future. The thugs aim to inspire awe with their van and gift of milk, but the scene switches to rebellion and dethroning, to use Bakhtin's term. The landlord, a parasite that keeps increasing the rent (especially Dad's, who keeps refusing to vote for the Party of the Rich), is pulled out of the van, dragged by the beautiful garments to which he clings: his magnificent blue agbada is torn to shreds, "like the feathers of a plucked parrot," (147) as if mock sparagmos (i.e. ritual dismembering) punished the parroting of the slogans; ${ }^{1}$ and the utterly undignified landlord ends up covered in white powder, a grotesque parody of a masquerade:

When the landlord next emerged his hair was covered in mud and someone spilt milk on him and he looked like a travesty of an Egungun and when he tried to get back on the van his fellow party men didn't let him because they didn't recognize him. (147)

The carnivalesque scene unleashes energy, allowing the joyous appropriation of milk. The ironic comparison with an Egungun underlines the landlord's betrayal. The Egungun ritual connects the mask-wearer with the power of ancestors; on the contrary, the grimy paste staining his face reveals that he is betraying value systems and the ancestors' legacy, through allegiance to the growing forces (or farce?) of pseudo-democracy. Apparent success, as the crowd conquers the van, is soon belied by general sickness, as

1. The parroted slogans are further mocked when the van returns and lies are exposed by the slip which gives a glimpse of truth: "WE ARE YOUR FRIENDS. WE WILL BRING YOU ELECTRICITY AND BAD ROADS, NOT GOOD MILK, I MEAN GOOD ROADS, NOT BAD MILK [...]” (180). 
the corrupt milk makes everyone ill - all except Azaro's family, protected as they are by Dad's defiant discarding of the milk.

Parasitic contamination thus concerns less a single individual than the community, the social body which is at stake: "it enters the body, and infests it. Its infectious power is measured by its capability to adapt itself to one or several hosts" (Serres 190). The bite of animal parasites is less to be feared than the multiplication of human parasites, preying upon the land. A toxic agent, the parasite changes the system, exciting it or paralyzing it, by trauma, by infection, by compression, despoiling like leeches, fleas, mosquitoes, "by irritations, inflammations, itching; by rashes": the parasite "enters the system as an element of fluctuation," it "changes its state, changes its energetic state, its displacements and condensations" (Serres 191). If milk may be vomited and purged after a while, it is not so easy to get rid of rampant corruption which seeps through the area and transforms it, twisting characters like the ambivalent Madame Koto.

\section{Smoke in the witch's soup}

Madame Koto and her bar are shape-shifters, and their problematic growth indexes the infection of the land. The nondescript bar, which Dad enters in the beginning simply because it is the first that he comes across along the path, grows more sophisticated during the course of the novel. It is rebuilt by a carpenter; graduating from palmwine to beer, it flaunts its allegiance to global economics with its Coca-Cola poster and mermaid calendar, symptoms of economic prostitution, along with the women now working for Madame Koto; it becomes a meeting place for strange customers, first spirits, then thugs and all the dubious show of wealth associated with the Party of the Rich. Connection to the powers-that-be is emblematized by the advent of electrical power: coloured bulbs compose the vanity fair of the stillborn nation. Whereas in the beginning Madame Koto seems a nurturer, a medicine woman who is able to return Mum's spirit to her body as she lies on the threshold of death, she soon proves a strange hostess when she puts a chicken's head in Azaro's soup and makes him chew its eyes, or when she orders a sizzling soup about, like a witch casting spells with food. She blurs gendered boundaries, throwing a customer who refuses to pay onto the ground like a farcical wrestler at a fair (and she shames him by stripping his pants); at times she is said to have a beard, other times she reinvents herself by laying on makeup and sporting a wig and red dress that entirely alter her appearance; she dances a grotesque seductive dance with a bemused Azaro. No wonder that the priest outside the bar should call her the whore of Babylon (the priest she shames not by wrestling with him but by offering him temptation - an umbrella in heavy rain). The car which she loves to drive too fast is an emblem of her hardened self - she squeezes into the tiny car to resemble a tortoise in a shell, a grotesque parody of one of the tutelary animals of Nigeria, and her carapace of technological progress signals only loss of direction (rather than modern circulation) along the mad, famished road of corruption.

Thus Madame Koto shifts from nurturer to parasite, joining the Party of the Rich; she closes her eyes to ongoing violence, as when she fails to interfere when a man seeks refuge in the bar; the man is briefly helped by Azaro but caught by the thugs, beaten up, then taken to the woods, presumably to be killed. The bar is a metonymy of the perversion of the nation. Beginning as a larger-than-life character, Madame Koto grows larger and larger, achieving monstrous proportions, partly because she has joined the ranks 
of parasites and is growing rich, partly because she is pregnant, but pregnant with three abiku children, the emblem of an abiku nation which cannot be properly born through Independence, and which unites the energy of its triple ethnic roots, Yoruba, Igbo and Hausa: "her stomach bloated with its abiku trinity" (Okri 567). For Felicia Oka Moh, "[t] he grotesque obesity of Madame Koto is symbolic of Nigeria" (82).

Koto's pregnancy and Azaro's attachment to life are part of Okri's distorsion of the abiku myth. Quoting Wole Soyinka, Christiane Fioupou stresses the "assimilative wisdom" of myth, its ability to evolve to reflect modern experience (145). Okri taps into traditional culture and literary representations, such as Soyinka's, whose abiku poem also adopts a first-person viewpoint. But Soyinka's abiku is a fierce spirit who preys upon its mother's grief and cannot be propitiated by "sacrifices, more sacrifices," (29) a goat or a plate of food. Traditionally the spirit-child is insensitive, cleaving rather than clinging, it delights in tormenting mothers; the oft-born abiku bears its mark defiantly, mocking the identifying trace left upon the skin; it keeps coming and going, an uncontrollable maker of mischief. Like Soyinka's, Okri's abiku is a palimpsest, the mark upon the skin functions as a symptom of writing and rewriting. But Azaro functions as the very opposite of the cruel spirit-child; he is drawn back to the human world by his mother's "bruised" face, by the suffering he senses and seeks to alleviate through his presence. He is spell-bound by the rainbow world of spirit-children, and runs the risk of being lured by the moonlight voices of his former friends, tempted by many-headed messengers (or violently abducted by disquieting spirits towards a more uncertain destination). Yet he ultimately chooses to stay in this world of limited prospects and harsh life, severely constrained by poverty. His is a journey along a famished road, where a mother's smile and storytelling are as nourishing as food. Though initially frightened of Dad (he runs away from him when the mother brings him back from the police officer's house), a father who proves violent at times and seeks to beat wandering out of him, Azaro develops a strong bond which is marked by his crucial intervention in each of his father's symbolic contests, from the game of draughts to the boxing matches (each time, the father is being defeated until Azaro steps in and either distracts the opponent, wards off an evil influence, or calls out to his father to unleash his power, a performative cry at the right moment, or kairos). The bond with the mother is established from the start, before Azaro is born, but it is highlighted by the significant shift, the mother's wish to die, which triggers overwhelming grief in her abiku child, in a significant reversal of the pattern: "I had chosen to stay, now she wanted to die. [...] She didn't know how unconsolable I was at that moment, because she didn't know the cause of my grief" (266). Longing to hear his mother say that she will never die (not the other way round), Azaro is a mutant abiku, differing from Ade or the unborn malevolent foetuses in Madame Koto's still, barren womb. Though Azaro does face the trials of abduction and near death, there is a sense of resilience which makes such episodes picaresque rather than fearful; so that the threat of cruel death (and the promise of rebirth in another historical cycle) is in fact displaced and metaphorically projected upon the country; the abiku myth is used as a metaphor to signal historical crisis and error, and as a means to unravel the reality of "precarious lives" through an outsider's eyes, ${ }^{2}$ not a stranger (especially not a white foreigner) but a narrator who both belongs and does not belong, and thus is be-

2. The expression is Judith Butler's in her eponymous book; and the outsider's naïve outlook is a device used by Montesquieu in his Lettres Persanes. 
mused by the strange comedy of human life. The outsider's gaze highlights the politics of existence.

\section{Buried secrets}

Modifying his abiku, Okri plays with traditional motifs to explore the failed transition to an independent democracy (thus it may be argued that the author feeds upon hybrid traditions to introduce noise, vibration, impurities within the motif to appropriate images and create his own mythopoeic method, a creative parasite in Serres's sense). For instance, Okri picks up the theme of the abiku's secret object, traditionally a stone, or a piece of clothing, a doll, or a hair which the abiku buries and which connects him with the other world, a connection which must be broken by a herbalist's rituals, forcing the child to confess where the object has been concealed (as is the case in Achebe's Things Fall Apart, where a pebble is the iyi-uwa, or secret link, of an ogbanje, the Igbo version of the abiku): "To sever the abiku's link to the spirit-world and bind him to his earthly home, the abiku's magic token, usually buried in a remote area, must be found and destroyed" (Lim 63). But in Okri's novel the link is not severed; Azaro retains the objects he buries in moonlight (recalling the moonlight voices of spirit-children in their rainbow world), both concrete objects and abstract promises:

I didn't want to lose contact with that other world of rainbows and lights and possibilities. I had buried my secrets early. I buried them in moonlight, the air alive with white moths. I buried my magic stones, my mirror, my special promises, my golden thread, objects of identity that connected me to the world of spirits. I buried them all in a special place, which I promptly forgot. (10)

Not only does Azaro forget about his secret objects in The Famished Road, but the motif reappears under a different guise, a variation which reverses the perspective. When Azaro encounters spirits and refrains from telling his parents, he buries the secret of his dual nature in his silence, or rather "plants" it like a seed, as when he hesitates before Madame Koto's bar: "I stayed outside for a while, planting my secrets in the silence of my beginnings" (288). The sibilant line is answered by a parallel motif, for Madame Koto too happens to be planting secrets in her backyard ("She was often digging the earth, planting a secret, or taking one out" [89]); though this seems at first to refer to plants, Azaro repeatedly sees her burying her white stones in the evening and digging them up during the day, "stones" which turn into her necklace of pearls:

Further on, hidden by the bushes, was Madame Koto's massive form. At first I thought she was doing something quite private, so I looked away. But when I looked again, she had straightened and was inspecting the white beads which she dug into the ground at night and unearthed in the day [...]. When I saw her next she was wearing the white beads round her neck. (120)

Presumably due to the fear of thieves, the gesture also functions like a ritual, as if the witch-like Madame Koto also drew strength from a habit that recalls the symbolic definition of the abiku. Burying, here, means tapping into obscure powers - as exemplified by the hordes of spirits that thrive in the bar, and by some secret presences such as the dark wind rushing into the soup, a soup which bubbles and spills yet calms down at Madame Koto's command, as if inhabited by a life of its own. The only way of toning down Koto's uncanny powers seems to be the reverse burial of a secret token, her mysterious fetish. 
From the start, Madame Koto sees in Azaro a strange child who may be of use in the bar, not so much because he performs menial tasks (indeed he adamantly refuses to be treated as a servant) but because he is meant to attract customers. As if his presence were not sufficient, Madame Koto hangs up a fetish, and Azaro infers that it is a magnet for spirits - and so the bar soon fills with strange customers like "bizarre actors," (126) who tend to be more uncontrollable than even Koto has bargained for. Endowed with his abiku's double vision, Azaro can hear multiple voices before they actually materialize, then (unlike the other human customers who fail to notice that the other visitors are unusual) he sees them as hybrid presences composed of ill-assembled body parts, with peculiarly disturbing dysfunctional eyes and disquieting designs. In order to fight the metamorphic spirits that may abduct him, Azaro steals the powerful fetish Madame Koto has put up on the wall. This leads to one of the many epic chases of the novel, as Azaro is pursued by a metamorphic Madame Koto: he rides "the invisible horse of the night," (162) followed by a cavalcade of voices as he gallops past statues with masks of gold and lapis lazuli eyes. Madame Koto's spirit flies after him, an implacable warrior who suddenly melts into the night until only the eyes are left (a variation on the Cheshire Cat's smile). Then Azaro instinctively decides to bury the fetish in the forest's clearing, a ritual gesture that mingles earth and water:

Then I decided to bury it, just in case the spirits or Madame Koto accidentally found it. I dug a hole with a stick. Water filled the hole. I didn't mind. I stuck the fetish into the hole and covered it over with wet earth and then I stuck branches and sticks around the hole to remind me where I had buried the fetish. (164)

Interestingly enough, the phrase "planting my secrets in my silence" (165) appears right after this episode, as if giving an abstract version of this concrete burial.

The term "planting" is given an uncanny echo when Azaro later returns to the place, finds a strange dual mask which he irresistibly puts on, and discovers that a strange tree has grown out of the fetish. This seems to subvert and parody the ritual which consists in burying an umbilical cord and planting a tree that will tap into the power of birth and protect the child. Here, on the contrary, the fetish secretly buried by Azaro gives birth to a monstrous tree:

Ordinary things became riddles. In the obscurity of things I saw what was different about the clearing. Something was standing there. A tree had grown there. It had grown in the spot where I had buried Madame Koto's fetish. It was an odd tree and in the dark it seemed like an animal asleep on its feet. It was shaped exactly like a bull without horns. It was a stout muscular tree, without leaves. It seemed comfortable to sit on, to play on, and I wanted to see the darkening world from the height of its back. (285)

The short sentences suggest the paradoxical alliance of growth and barrenness, in a forest full of wondrous apparitions. The rugged remote patch in the interior of the forest becomes an enticing place, as the tree tempts Azaro into climbing it; when he does so, not only does a hungry, frightening ancient creature appear before him, "a creature ugly and magnificent like a prehistoric dragon," (286) part warthog, part elephant, a "devourer" of lost souls, lost spirits, lost humans, but the tree beneath Azaro begins to move, and Azaro realizes that he is sitting on a monstrous creature too, and that the wood has turned into flesh: "I realised that I had made a terrible mistake, and that I was riding on the back of a wild animal, awoken from a fetishistic sleep" (286). As the 
two animals crash and fight, Azaro manages to rip the mask off his face, jump to the ground and run away.

The scene is part of the uncanny manifestations which create the magic of the novel, its spellbinding power. It plays on the powers of vision and transformation traditionally associated with masks, and according to Brenda Cooper suggests that Azaro is not mature enough to wear the mask carved by a patient artist (286). But the mask may also recall Frantz Fanon's 1952 book Peau noire, masques blancs, depicting the divided self-perception of the Black subject who has been forced to embrace the culture of the white "mother" country. Because he has lost his own cultural tradition, he is compelled to attempt to appropriate and imitate the culture of the colonizer; here too Azaro cannot tear the mask from his face, but the mask is African and the motif is transformed. What is at stake is no longer the colonizer's ethos, but the new face of power and corruption, an African mask which may have become as crippling as the previous masks imposed by colonization. Thus the passage might also read like a parable: the tree which grows from the fetish is barren yet powerful, it turns into a monstrous animal which rushes to combat and heads towards destruction, which can neither be ridden nor tamed. This could be a metaphor for the future that rises out of evil and corruption, out of Madame Koto's alliance with the new powers-that-be, emblematized by the fetish. Out of such powers can only grow evil, barrenness, not a tree of life, but an animal taking its rider for an unmanageable, monstrous ride. The mother-figure, the nurturing presence, turns into the figure of a potentially still-born nation.

\section{Bleeding trees and broken backs}

This is why, perhaps, the totems of fertility in the novel, from the statue on the island of the silent women (who abduct Azaro, presumably as a sacrifice to propitiate the goddess) to the snail-covered statue with bright red eyes in Madame Koto's room, may be connected with totems of loss, broken trees: "We passed a tree that had been felled. Red liquid dripped from its stump as if the tree had been a murdered giant whose blood wouldn't stop flowing" (20). The novel is haunted by deforestation; the road is the road of destiny and road accidents, as it was for Soyinka, but it is also a greedy monster eating up space itself, just as the King of the Road ends up eating its own body, leaving a mere stomach which dissolves into the road. The road which is being carved simply devours the landscape as it exists, as Dad tells Azaro early on in the novel: "But sooner than you think there won't be one tree standing. There will be no forest left at all. And there will be wretched houses all over the place. This is where the poor people will live" (42). In Azaro's final bird's eye view of time, when he sees through a duiker's eyes, he moves from a vision of colonial conquest to a vision of wood spirits flying away and trees retreating, screaming. For Coral Wu, deforestation in The Famished Road triggers both an ecological and a cultural crisis (102). And it is no wonder that the children should gaze in awe at a white engineer who enters a tent and comes out as a black man - an episode which functions both as a humorous focalization on children and a parable suggesting that there may be little to choose between colonial powers and the people who step into their shoes, their black skin belied by profiteering.

This cultural crisis is also at work within the community. Jean-Luc Nancy, in La Communauté déscuvrée, explores the contrast between the disenchanted, inoperative community (where people are unable to relate and manage to be together) to being-with, 
"l'etre-en-commun," an ontological social condition (201). The novel explores the shift from being-with to a semi-inoperative community through storytelling and the abortive feast scenes, which both function and do not function as cathartic communal rituals. In the most significant one, Mum and Dad celebrate Azaro's return from the police officer's house with a boar Dad has killed in the forest. Just as Dad seems to abide by ancient hunting rituals, Mum skins the boar with other women and cooks it into an aromatic feast, and men and women begin to sing humorous songs which signal harmony and tradition. But the feast is disrupted as uninvited people begin to pour in, the room becomes packed, and there remains but a morsel of food for each (invited or uninvited) guest, a parody of the miracle of loaves and fishes in reverse. Thus intruders (the uninvited guests) create the parasitic noise described by Michel Serres and subvert the banquet. Instead of food, which remains scarce, drinks begin to flow, and Dad sends for more and more ogogoro, turning the gift of food into financial debt; he is plagued from then on by creditors, who seek to deprive him of furniture and boots, the biggest parasite being of course the landlord, who begins as a semi-genial presence and quickly turns into a threatening exploiter in the novel. Dad is irked by the creditors because they have eaten his food and drunk with him - so that communal sharing is replaced by sponging. For Michel Serres,

To parasite means to eat next to. Let us begin with this literal meaning. [...] But that is not enough; it never was. The relation of the guest is no longer simple. [...] Abuse appears before use. Gifted in some fashion, the one eating next to, soon eating at the expense of, always eats the same thing, the host [...]. (7)

A parody of communion, the feast frustrates everyone, leaving the creditors to claim everything they can, a surrogate attempt to feast upon Black Tyger's body. As the novel proceeds through systematic incremental repetition, the dynamic of the aborted feast that fails to strengthen communal ties is repeated, culminating with the celebration of Dad's fight and the arrival of layers of uninvited guests, including the horde of beggars. Neither the feasts nor the lovely pepper-soup at Madame Koto's bar function as rites of sharing; instead of establishing "être-en-commun," they simply draw hordes of parasites, uninvited guests on the one hand, spirits and thugs on the other.

And perhaps this is why the structure of the novel too may be seen in terms of incremental repetition and parasitic interference or repetitive vibrations, echoing waves of difference and repetition. For there is an eerie similarity between episodes involving spirits and thugs, as if the novel played upon the vicious circle of repetition. Dad must fight the strange spirit risen from the swamp, whose yellow eyes join the body as an afterthought, just as he must later fight Green Leopard and the man in a white suit, as if the spectral apparition simply paved the way for the thugs' champions. Regaining his dignity as he reinvents himself as Black Tyger, Dad taps into an energy which comes from all kinds of ancestors, including his father, the Priest of the God of the Road (and implicitly Ogun, the God of the Road, and Shango, the God of Lightning, placing fire in his fists), and also, as the spelling of the name suggests, the poet of energy, William Blake. Even more striking, perhaps, is the variation on the market scene; far from being, as it is for Soyinka for instance, the heart of the life of the community and the world itself, the market functions as a system of interference and parasitic "noise," where Azaro sees spirits eating and picking goods, and is pursued though he pretends to be unable to see them. In the second great market scene, Azaro is faced with a web of voices (much 
like erratic white noise), and made to eat a strange kind of food which plunges him into an eerie trance. As he drifts from stall to stall, he sees thugs knocking down a stall, a woman fighting and picking up her goods - only after the scene is repeated a number of times does he identify the woman as his mother. The shift from spirits to thugs creates a pang of awareness in the reader too - the true parasites are not so much the supernatural spirits as the ruthless, mindless thugs. This process of delayed decoding is particularly efficient, and as great a shock is created when the roaming Azaro chances upon, not a bunch of metamorphic many-eyed spirits, but men crushed by sacks, sacks of cement and salt, at the garage. Among the men Azaro suddenly recognizes his father's voice, and understands for the first time the source of his father's physical pain and shame.

To conclude, the novel mingles motifs and plays on repetitions and echoes to create variations on traditional Nigerian myths and stories, in order to engage with the nation's inability to reinvent itself and rise up to the challenge of Independence. As we have seen, playing with parasitic noise, interference and repetition, Okri explores the dynamics of parasitic transformation, through the ambivalent character of Madame Koto, a helper seduced by the new powers; through aborted feasts and the disquieting shift from spirits to thugs, showing the confrontation between symbolic violence and precarious lives, Okri engages with the paradigmatic shifts brought about by a political democracy which already retains little more of democracy than the name (as is suggested early on by the scene at the police officer's, where the bloody ghosts lurking are not parasites but former victims of the officer, whereas the true parasites for the community are the men visibly drawn together by shady deals, and pledging an oath of corruption, a moth hovering by to signal potential traitors, associating the insect with the corrupt social parasite). But Michel Serres also hints that there may exist a more positive kind of parasite, a parasite who invents something new: "He crosses the exchange, makes it into a diagonal. [...] People laugh, the parasite is expelled, he is made fun of, he is beaten, he cheats us; but he invents anew" (35). This erratic parasite may be the photographer, who slips into the scene and loses his name, Jeremiah, taking pictures which people cannot pay for, then grows into an International Photographer who slips in and out of scenes which he turns into events by bearing testimony, framing and fixing them, making them exist in the eyes of the world. An essential witness, the photographer is a parasite who documents life, poverty and riots, and thus functions as the author's double, as Vanessa Guignery stresses: "Jeremiah, a figure of the artist, can be seen as an alter ego of the writer in the way in which he engages with the world [...]. While The Famished Road is neither a political book nor a historical novel, it certainly engages with the world at large, or, one might say, with the coterminous worlds and realities" (171).

Catherine LANONE University of Paris 3-Sorbonne Nouvelle

\section{Works Cited}

AcheBe, Chinua. Things Fall Apart. 1959. New York: Fawcett Crest, 1969.

BAKHTIN, M. Rabelais and His World. 1965. Trans. Hélène Iswolsky. Bloomington: Indiana UP, 1993. ButLer, Judith. Precarious Life: The Powers of Mourning and Violence. London: Verso, 2004.

Costantini, Mariaconcetta. Behind the Mask: A Study of Ben Okri's Fiction. Rome: Carocci, 2002.

CoOper, Brenda. Magical Realism in West African Fiction: Seeing with a Third Eye. London: Routledge, 1998. 
De Montesquieu, Charles-Louis. Lettres Persanes. 1721. Paris: Gallimard, 1973.

Dickens, Charles. David Copperfield. 1850. London: Penguin, 2004.

ELDER, Arlene. Narrative Shape-Shifting: Myth, Humor and History in the Fiction of Ben Okri, B. Kojo Laing and Yvonne Vera. Oxford: James Currey, 2009.

Fanon, Frantz. Peau noire, masques blancs. 1952. Paris: Honoré Champion, 2013.

Fioupou, Christiane. Réalité et représentation dans l'auvre de Wole Soyinka. Amsterdam: Rodopi, 1994.

Fraser, Robert. Ben Okri: Towards the Invisible City. Horndon: Northcote House, 2002.

Guignery, Vanessa. Seeing and Being: Ben Okri's The Famished Road. Paris: CNED / PUF, 2012.

Lim, David. The Infinite Longing for Home: Desire and the Nation in Selected Writings of Ben Okri and K.S. Maniam. Amsterdam: Rodopi, 2005.

Nancy, Jean-Luc. La Communauté déscuvrée. Paris: Christian Bourgois, 1986.

Okri, Ben. The Famished Road. 1991. London: Vintage, 2003.

MoH, Felicia Oka. Ben Okri: An Introduction to his Early Fiction. 2001. Port Harcourt: Amethyst \& Colleagues Publishers, 2005.

O'CONNOR, Maurice. The Writings of Ben Okri: Transcending the Local and the National. New Delhi: Prestige, 2008.

QuaYson, Ato. Strategic Transformations in Nigerian Writing. Orality and History in the Work of Rev. Samuel Johnson, Amos Tutuola, Wole Soyinka and Ben Okri. Bloomington: Indiana UP, 1997.

RusHDIE, Salman. Midnight's Children. London: Jonathan Cape, 1981.

Serres, Michel. The Parasite. Trans. Laurence R. Schehr. Minneapolis: U of Minnesota P, 2007.

SoyinKA, Wole. Idanre and Other Poems. London: Methuen, 1967.

STERne, Laurence. Tristram Shandy. 1760-1767. Ed. Howard AndERson. New York: Norton, 1980.

Wu, Coral. "From Cultural Hybridization to Ecological Degradation: The Forest in Chinua Achebe's Things Falls Apart and Ben Okri's The Famished Road." JALA: Journal of the African Literature Association 6.2 (Winter/Spring 2012). 1-21. March 13, 2013

$<$ http://www.africanlit.org/publications/jala/Vol6No2/wu.pdf > . 